九州大学学術情報リポジトリ

Kyushu University Institutional Repository

\title{
DISCOVERY OF THE NEARCTIC GENUS CHASMATONOTUS LOEW (DIPTERA, CHIRONOMIDAE) FROM JAPAN, WITHDESCRIPTIONS OF THREE NEW SPECIES
}

Yamamoto, Masaru

https://doi.org/10.5109/2404

出版情報 : ESAKIA. 15，pp.79-96，1980-10-31. Entomological Laboratory，Faculty of Agriculture， Kyushu University

バージョン：

権利関係 : 


\title{
DISCOVERY OF THE NEARCTIC GENUS CHASMATONOTUS LOEW (DIPTERA, CHIRONOMIDAE) FROM JAPAN, WITH DESCRIPTIONS OF THREE NEW SPECIES*
}

\author{
M ASARU YAMAMOTO \\ Entomological Laboratory, Faculty of Agriculture \\ Kyushu University, Fukuoka 812, Japan
}

\begin{abstract}
The chironomid genus Chasmatonotus, which has been known from the Nearctic Region, is reported from Japan for the first time. Three new Japanese species, Chasmatonotus unilobus, Chasmatonotus parabicolor, and Chasmatonotus saigusai, are described and figured.
\end{abstract}

The genus Chasmatonotus was proposed by Loew in $\mathbf{1 8 6 4}$ for a single species C. unimaculatus from New Hampshire, U. S. A. After that, Osten Sacken described C. bimaculatus in 1877 from Quebec. Coquillett described C. univittatus in 1900 from Alaska, and fascipennis from British Columbia and hyalinus from California in 1905. In 1937 Rempel revised the genus and described 3 additional species, i.e., atripes from New York, bicolor from Tennessee and maculipennis from Washington. He pointed out that the species identified by Johannsen (1905) and Malloch (1915) as bimaculatus 0 . S. was atripes. He also stated that maculipennis is probably a Palaearctic species, because the specimens on which his description was based were those intercepted in quarantine at Seattle in Washington on Japanese maple from Japan. Thus the genus is hitherto represented by eight species which are distributed exclusively in the Nearctic Region.

Some twenty years ago Prof. T. Saigusa of Kyushu University collected several specimens of curious chironomid midges at the subalpine to alpine zones of Central Mountain Region of Honshu, and he granted them to me. In 1977 I obtained many specimens of a similar midge at the subalpine zone of Amô Tôge, Gifu Pref., Honshu. When he visited Kyushu University in 1978, Prof. J. E. Sublette of Eastern New Mexico University suggested me that these midges belong to the genus Chasmatonotus. After a close examination of

* Contribution from the Entomological Laboratory, Faculty of Agriculture, Kyushu University, Fukuoka (Ser. 3, No. 79). 
the male genitalia of these midges, I found out that they represent three species. All of these Japanese species are closely allied to bicolor not only in the wing marking but also in the general structure of the male genitalia, but are very distinct in detailed structure of the latter. Therefore I will describe them as new species in the following lines. I do not still find maculipennis in Japan which was suggested to be introduced from Japan to Washington, as stated before. However, thanks to Prof. J. E. Sublette, it became clear that the genus Chasmatonotus is also distributed in the Eastern Palaearctic Region.

The genus Chasmatonotus is readily distinguishable from any other chironomid genera by having a median longitudinal fissure on the mesoscutum and for Japanese species by having the five antenna1 flagellomeres in both sexes. The latter character is also found in male of African genus Harrisonina Freeman.

Japanese species of the genus Chasmatonotus are found in the mountainous regions of the Japan Alps and neighbouring mountains, especially at the moist herbaceous places in woods. Prof. T. Saigusa and I observed that the midges were actively walking about on the ground and on the herb, but did not observe them on wings, although they have well developed wings. I also observed the species collected at Am8 Tôge was mating on the ground or on the herb near the high moor in woods. So far as I know, the immature stages of this genus have not been clarified but I think they are probably terrestrial considering the environment in which they live, so far as the Japanese species are-concerned.

Before going further I express my grateful thanks to Prof. Y. Hirashima and Assoc. Prof. K. Morimoto, Entomological Laboratory, Faculty of Agriculture, Kyushu University for their constant guidances. I wish to express my cordial thanks to Prof. T. Saigusa, Biological Laboratory, College of General Education, Kyushu University, for his kind guidance in preparing this paper and giving me an opportunity to examine the interesting materials. My thanks are also due to Prof. J. E. Sublette, Eastern New Mexico University, U. S. A., for his kind suggestion on the systematic position of the midges. I am much indebted to Mr. K. Ôhara, Kyushu University, for valuable specimens.

\section{Genus Chasmatonotus Loew}

Chasmatonotus Loew, 1864: Bed. ent. Z. 8: 50. Type-species : Chasmatonotus unimaculatus Loew, 1864.

Three new Japanese species of Chasmatonotus described below unexceptionally bear the generic characters mentioned by Rempel (1937) excepting the presence of the acrostichal setae and 5 flagellomeres, instead of 6 , of antennae. The acrostichal setae which are found in Japanese species are so minute that I suppose Rempel probably overlooked them on the Nearctic species. 
The characteristics of Japanese species are summarized as follows:

Head (Figs. Z-A, -B) small, placed under antepronotum; compound eye small, semicircular, widely separated from each other; prefrons and area surrounding antenna1 scape membranous; antenna1 flagellum composed of 5 flagellomeres in both sexes; gena with O-6 setae ; maxillary palpus with 5 segments but 1st segment membranous and indistinct.

Thorax (Figs. 3-A, -B) rather long; antepronotum well developed, deeply divided in middle ; scutum with a deep median longitudinal fissure which sparsely bears very minute acrostichal setae; dorsocentral setae irregularly uni- to triserial, stouter and longer on prescutellar area; supra-alar setae present or absent; scutellar setae in a double row; preepisternum with 3-18 setae on upper area; anapleural suture disappearing in middle.

Legs long and stout; fore-, middle and hind tibiae with 1,2 and 2 apical spurs respectively which bear scales at basal $1 / 2$; apical spurs of middle tibia subequal in length; outer spur of hind tibia longer than inner one ; basal two tarsomeres of middle and hind legs provided with a pair of spines apically which are bare and subequal in length; tibia1 comb of hind leg composed of 10-16 spines ; pulvilli well developed and pad-like ; empodium long and filiform.

Wing black with a white basal marking which extend into a narrow stripe; anal lobe not produced; squama unfringed but with $\mathrm{O}-5$ sparse setae; $\mathrm{R}_{2+3}$ obsolete or obvious, variable within a species; $M$ ending slightly beyond tip of $R_{4+5}$; fCu below $r-m$; costa, $R, R_{1}$ and $R_{4+5}$ with prominent suberect setae.

Male genitalia with gonopod variable in shape; epandrium flattened, with anal point short and stout but prominent; gonocoxite with or without basal lobes, inner surface of ventrodistal portion of gonocoxite with some short setae or long curved setae; gonostylus finger-shaped with a basal projection or subtriangular, and with a few stout spines near apex. Ninth abdominal tergite of female deeply emarginate in middle; laterosternite with a prominent apical projection. Spermatheca 2 in number, large.

Keys to Japanese Species of the Genus Chasmatonotus

\section{MALES}

Gonostylus slightly tapering, almost parallel-sided in lateral aspect, with a ventrally produced basal projection; gonocoxite with prominent basal lobes; anal

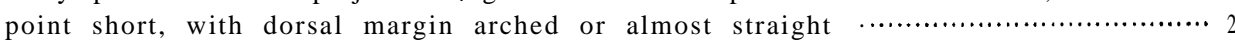
Gonostylus subtriangular in shape; basal lobe of gonocoxite only slightly swollen; anal point moderately long, blade-shaped, with dorsal margin weakly

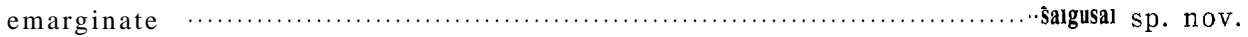

2. Gonocoxite in ventral aspect wide and nearly parallel-sided, with inner margin much expanding inwardly, almost straight; basal projection of gonostylus bilobed at tip; anal point with dorsal margin arched .................... unilobus sp. nov. Gonocoxite in ventral aspect tapering towards tip, with inner margin not expanding inward but strongly angulate in middle; basal projection of gonostylus simple; anal point with dorsal margin almost straight $. . . \ldots \ldots \ldots \ldots . . . .$. parabicolor sp. nov. 


\section{FEMALES}

1. Basal part of laterosternite simple, without a basal lobe; apical projection of laterosternite long, almost extending to posterior margin of tergite IX

- Basal part of laterosternite strongly projected into a lobe, apical projection of laterosternite short, ending much before posterior margin of tergite IX .........

unilobus sp. nov.

2. Apical projection of laterosternite stout, 8.7 as long as thick in lateral as-

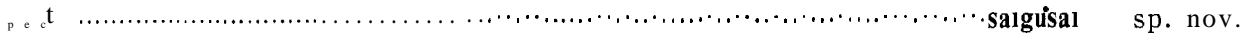

- Apical projection of laterosternite slender, $17.8 \times$ as long as thick in lateral aspect parabicolor sp. nov.

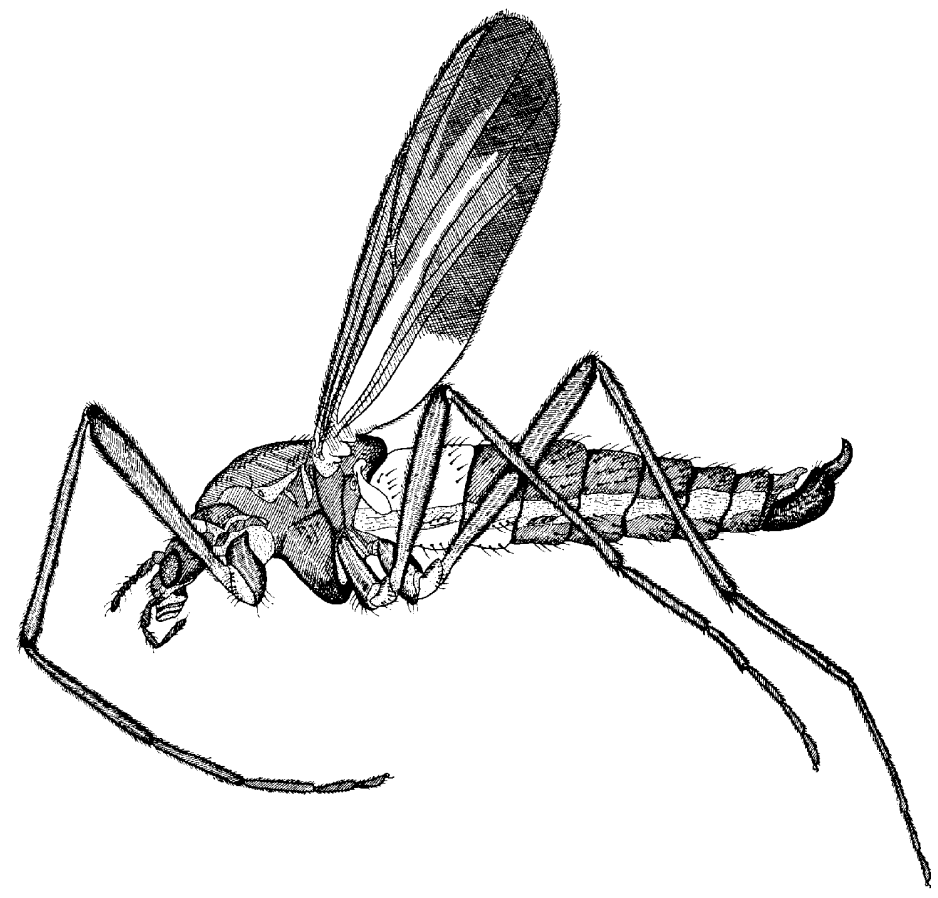

Fig. 1. Chasmatonotus unilobus sp. nov., ô.

\section{Chasmatonotus unilobus sp. nov.}

ð. Colouration: Head subshining brownish black; antennal pedicel brownish black, thinly grey pollinose, flagellum brown; clypeus, maxillary and labial palpi brownish black. Thorax with antepronotum brown with light yellow tinge to brownish black, postpronotum brown, sometimes with yellowish tinge; mesonotum subshining brownish black; scutum yellowish brown at anterolateral corner or entirely brownish black; scutellum and postnotum entirely brownish black. Thoracic pleura subshining brownish black, thinly grey pollinose. 
Legs including coxae predominantly subshining brownish black, thinly grey pollinose; all trochanters brown, slightly tinged with yellow; extreme bases of all femora slightly tinged with yellow; spurs of all tibiae black, spines of 1st to 2nd tarsomeres of middle and hind legs black. Wing strongly infuscated, with blackish veins ; apical $2 / 5$ of cell $R_{5}$, apical $1 / 4$ of cell $M$, apical $1 / 3$ of cell $\mathrm{Cu}$, apical $1 / 2$ of cell $\mathrm{A}$ behind $2 \mathrm{~A}$ much darkened, blackish; basal $1 / 4$ of wing whitish from $M$ to hind margin; this white area produced into a narrow stripe which extends to apical $3 / 4$ of wing. Halter yellow. Abdomen predominantly brownish black, thinly grey pollinose; basal 2 terga and basal 3 sterna yellow. Genitalia brownish black, thinly grey pollinose.

Head: Antennal flagellomere lengths $(\mu): 96,43,38,40,66$. First to 5th flagellomeres with 12-17, 5-6, 5-6, 6-7, 5-7 setae respectively, Antennal ratio, range $0.26-0$. 36, mean 0.30 . Second to 5 th palpal segment lengths $(\mu): 64$, $126,123,171$, and the palpal segments with 7-13, 37-49, 28-42, 20-31 setae respectively, Vertex, clypeus and gena with 24-42, 13-23, 1-3 setae respectively.

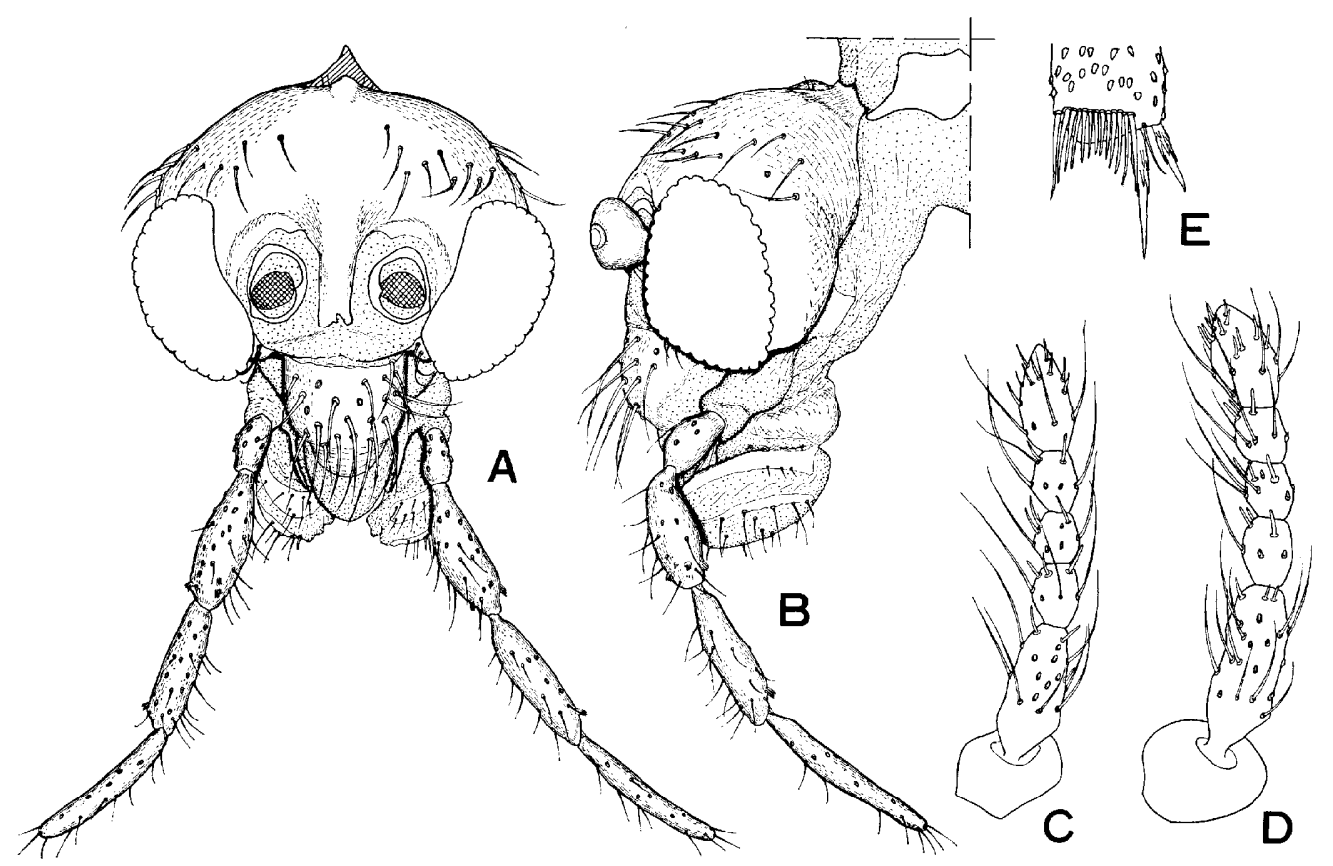

Fig. 2. Chasmatonotus unilobus sp. nov. A: head, frontal aspect, $\widehat{\jmath}$. B: same, lateral aspect. C: antenna, $\sigma^{7}$. D: same, ơ. E. tip of hind tibia, $\sigma^{7}$.

Thorax : Lateral antepronotals 7-11, median antepronotals 7-12 ; dorsocentrals 11-23, irregularly biserial ; acrostichals 11-17, prealars 5-11, supra-alars 0-2 ; scutellars 17-20, biserial. Preepisternum with 6-10 setae. 


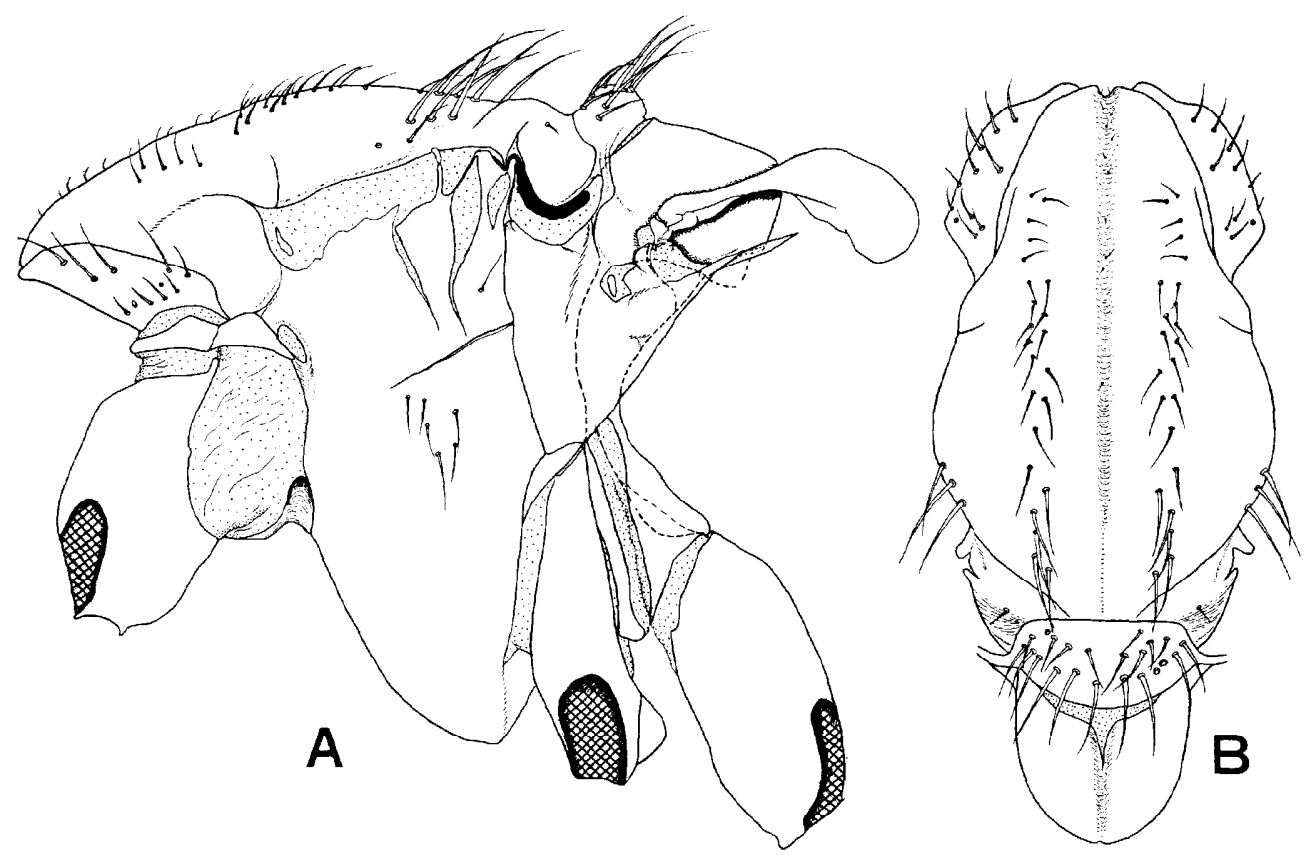

Fig. 3. Thorax of Chasmatonotus unilobus sp. nov., ठ.A : lateral aspect. B: dorsal aspect.

Legs : Fore-, middle and hind coxae with 28-36, 12-23, 23-32 apical setae respectively. Middle coxa with 9-10 minute sensory hairs on middle portion of outer surface. Fore-, middle and hind trochanters with 26-34, 23-32, 23-31 apical setae respectively. Outer spur of hind tibia 1.6-I. $9 \times$ as long as inner one. Tibial comb of hind leg composed of 13-14 spines.

Lengths (means, $0.01 \mathrm{~mm}$ in unit) and proportions (ranges and means) of legs :

\begin{tabular}{ccccccccccc}
\hline & $\mathrm{F}$ & $\mathrm{T}$ & $\mathrm{Tal}$ & $\mathrm{Ta} 2$ & $\mathrm{Ta} 3$ & $\mathrm{Ta} 4$ & Ta5 & BV & SV & LR \\
\hline $\mathrm{P}_{1}$ & 116 & 116 & 74 & 43 & 30 & 20 & 15 & $2.74-2.96,2.87$ & $2.94-3.37,3.12$ & $0.61-0.66,0.64$ \\
$\mathrm{P}_{2}$ & 109 & 113 & 48 & 28 & 21 & 14 & 13 & $3.33-3.79,3.52$ & $4.26-4.89,4.57$ & $0.40-0.49,0.43$ \\
$\mathrm{P}_{3}$ & 127 & 135 & 70 & 37 & 28 & 15 & 14 & $3.44-3.61,3.52$ & $3.62-3.96,3.72$ & $0.50-0.54,0.52$ \\
\hline
\end{tabular}

Wing (Fig. 4-A) : Length 1.9-2.1 mm. Width 0.6-O. $7 \mathrm{~mm}$. L/WR, range 3.04-3.38, mean 3.23. VR, range 0.94-I. 03, mean 1.00. $R, R_{1}$ and $R_{4+5}$ with 31-53, 11-22, 26-41 setae respectively. Radialis with 7-9 annular organs on its basal part, 1-2 annular organs on middle anteriorly, 5-9 annular organs on apical part, and with 3-6 setae near middle. Squama with 0-3 setae.

Genitalia (Figs. 6-A, -B, -C, -D) : A nal point (Fig. 5-A) short, arched dorsally at basal $1 / 3$. Gonocoxite comparatively wide and nearly parallel-sided in ventral aspect, apical to inner margin of its ventral surface much expanded 
and covering its ventrodistal surface and base of gonostylus; inner surface of ventrodistal portion with about 10 short setae; dorsal part of basal lobe only slightly swollen, ventral part of basal lobe projected into a short, slender process. Gonostylus moderately long, weakly bent inwardly in middle ; basal part strongly projected inwardly, bilobed at tip; extreme tip with a strong spine.

Length of body: $1.8-2.8 \mathrm{~mm}$.

우. Colouration almost as in male but thorax including antepronotum entirely brownish black. All trochanters and basal parts of all femora darker than in male. Cercus yellow.

Head: Antenna1 flagellomare lengths $(\mu): 116,45,40,41,76$. First to 5 th flagellomeres with $10-21,5-6,6-7,6-7,5-10$ setae respectively. Antenna1 ratio, range 0.28-o. 33, mean 0.31. Second to 5th palpal segment lengths $(\mu)$ : $77,150,150,186$, and the palpal segments with 8-15, 42-56, 38-53, 25-41 setae
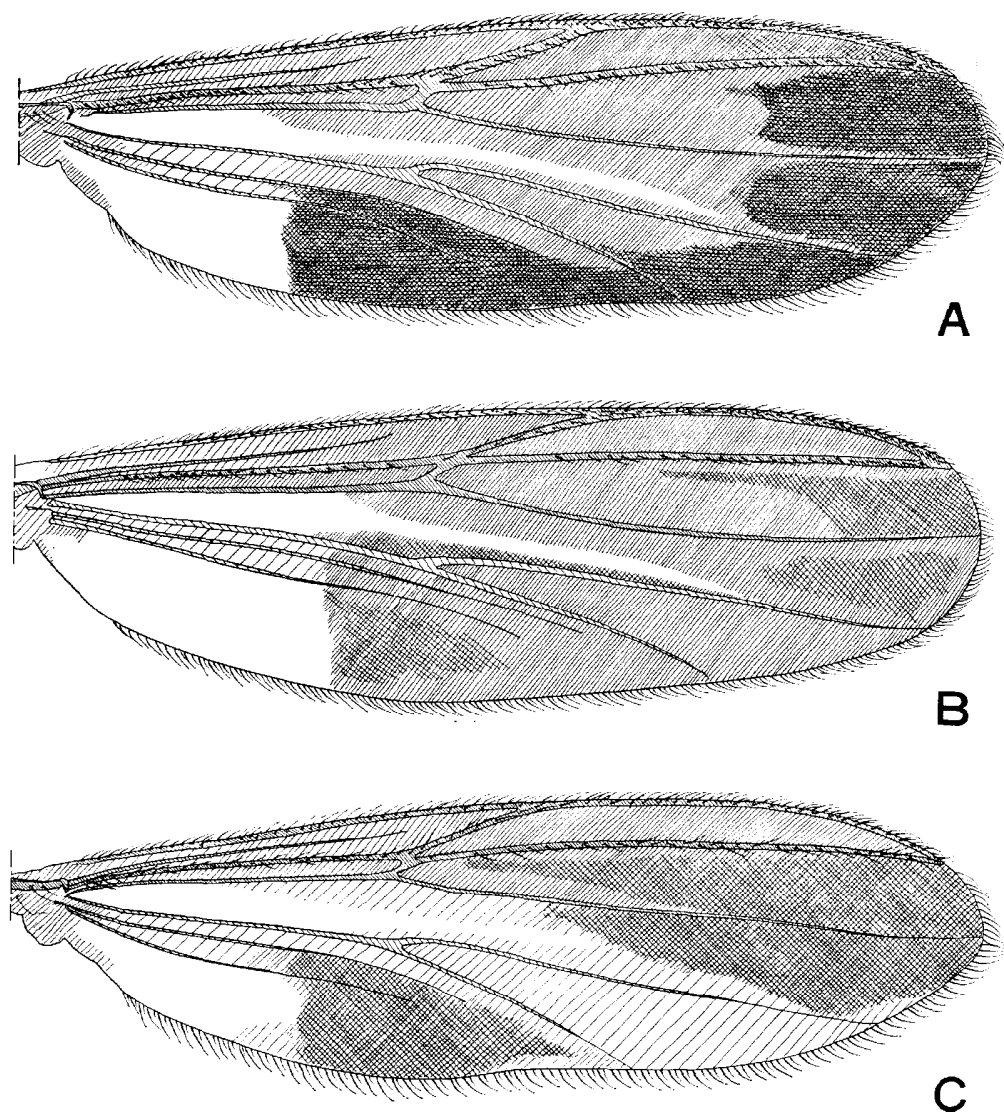

Fig. 4. Male wings of Chasmatonotus spp. A :Chasmatonotus unilobus sp. nov. B : Chasmatonotus parabicolor sp. nov. C: Chasmatonotus saigusaisp. nov. 

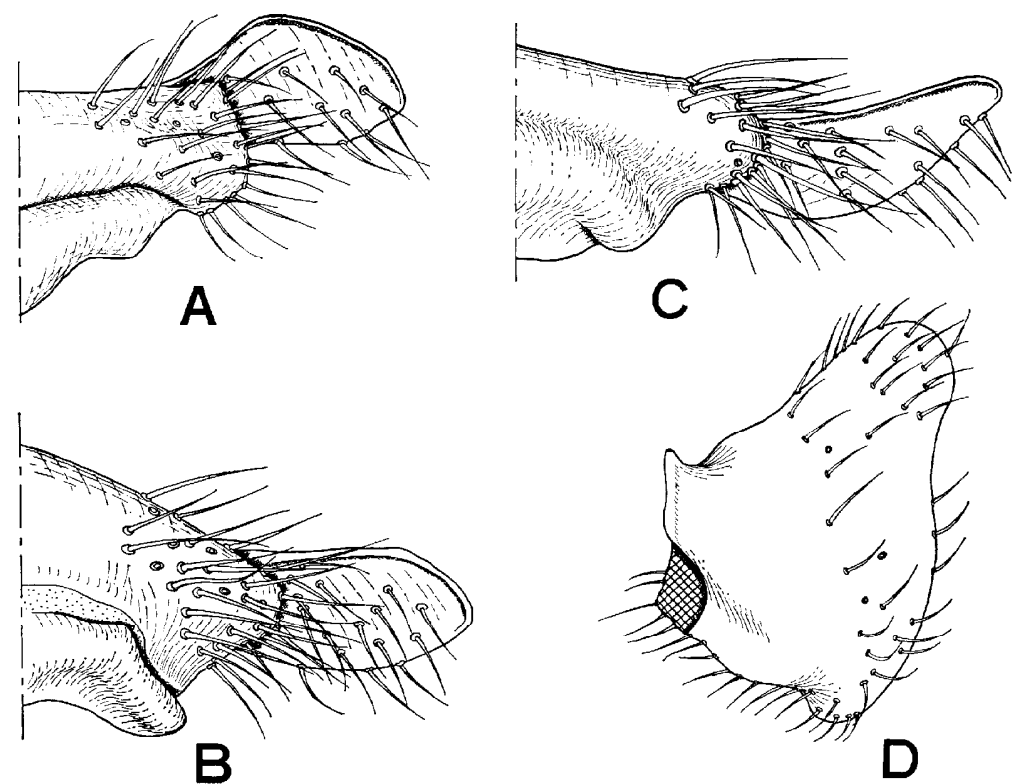

Fig. 5. Anal point (A-C) and gonostylus (D) of Chasmatonotus spp. A: Chasmatonotus unilobus sp. nov., lateral aspect. B: Chasmatonotus parabicolor sp. nov., lateral aspect. C: Chasmatonotus saigusai sp. nov., lateral aspect. D: Chasmatonotus saigusai sp. nov., dorsal aspect.

respectively. Vertex, clypeus and gena with 28-62, 19-30, 2-6 setae respectively.

Thorax: Lateral antepronotals 11-19, median antepronotals 7-14, dorsocentrals 26-31, irregularly bi- to triserial ; acrostichals 9-21, prealars 5-13, and no supra-alar ; scutellars 22-32, biserial. Preepisternum with 4-18 setae.

Legs : Fore-, middle and hind coxae with 33-50, 17-28, 32-47 apical setae respectively. Middle coxa with 9-11 minute sensory hairs on its middle portion of outer surface. Fore-, middle and hind trochanters with 30-45, 26-42, 30-37 apical setae respectively. Outer spur of hind tibia 1.6-1. 8x as long as inner one. Tibia1 comb of hind leg composed of 14-16 spines.

Lengths (means, $0.01 \mathrm{~mm}$ in unit) and proportions (ranges and means) of legs :

\begin{tabular}{ccccccccccc}
\hline & $\mathrm{F}$ & $\mathrm{T}$ & $\mathrm{Tal}$ & $\mathrm{Ta} 2$ & $\mathrm{Ta} 3$ & $\mathrm{Ta} 4$ & $\mathrm{Ta} 5$ & $\mathrm{BV}$ & $\mathrm{s}$ & $\mathrm{LR}$ \\
$\mathrm{P}_{1}$ & 123 & 127 & 75 & 41 & 30 & 21 & 16 & $2.95-3.24,3.04$ & $3.24-3.39,3.32$ & $0.57-0.61,0.60$ \\
$\mathrm{P}_{2}$ & 119 & 123 & 48 & 27 & 23 & 15 & 14 & $3.36-3.80,3.65$ & $5.00-5.28,5.10$ & $0.37-0.40,0.39$ \\
$\mathrm{P}_{3}$ & 139 & 150 & 75 & 40 & 31 & 17 & 12 & $3.04-3.69,3.53$ & $3.00-4.16,3.85$ & $0.45-0.60,0.50$ \\
\hline
\end{tabular}

Wing: Length 2.2-2.7 mm. Width 0.7-O. $9 \mathrm{~mm}$. L/WR, range 2.76-3.10, mean 2.96. VR, range 0.90-1.06, mean 1.00. $R, R_{1}$ and $R_{4+5}$ with 42-64, 13-20, 31-42 setae respectively. Radialis with 7-9 annular organs on its basal part, 

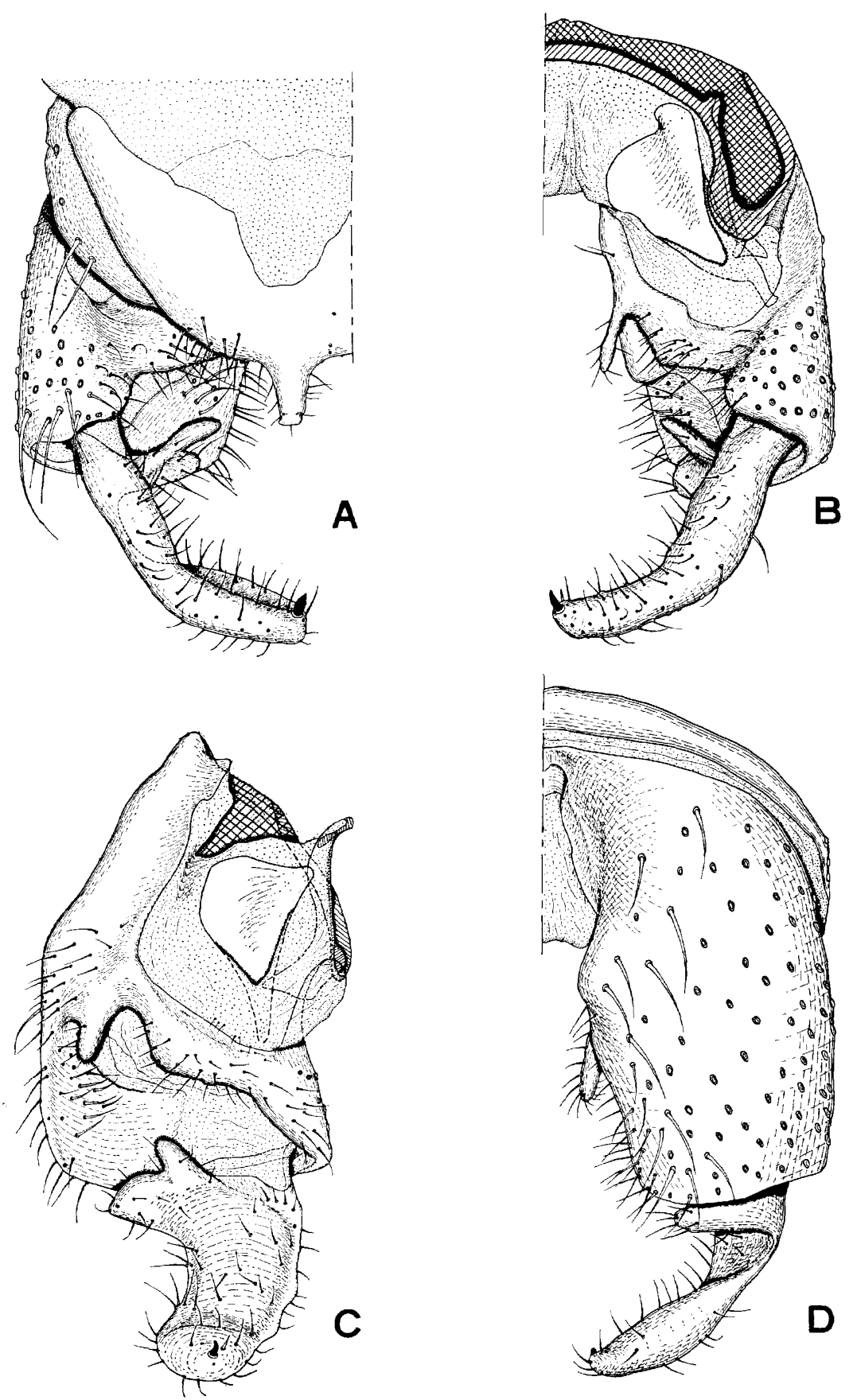

Fig. 6. Male genitalia of Chasmatonotus unilobus sp. nov. A: epandrium, gonocoxite and gonostylus in dorsal aspect. B: gonocoxite and gonostylus in dorsal aspect. C: same, inner lateral aspect. D: hypandrium, gonocoxite and gonostylus in ventral aspect. 

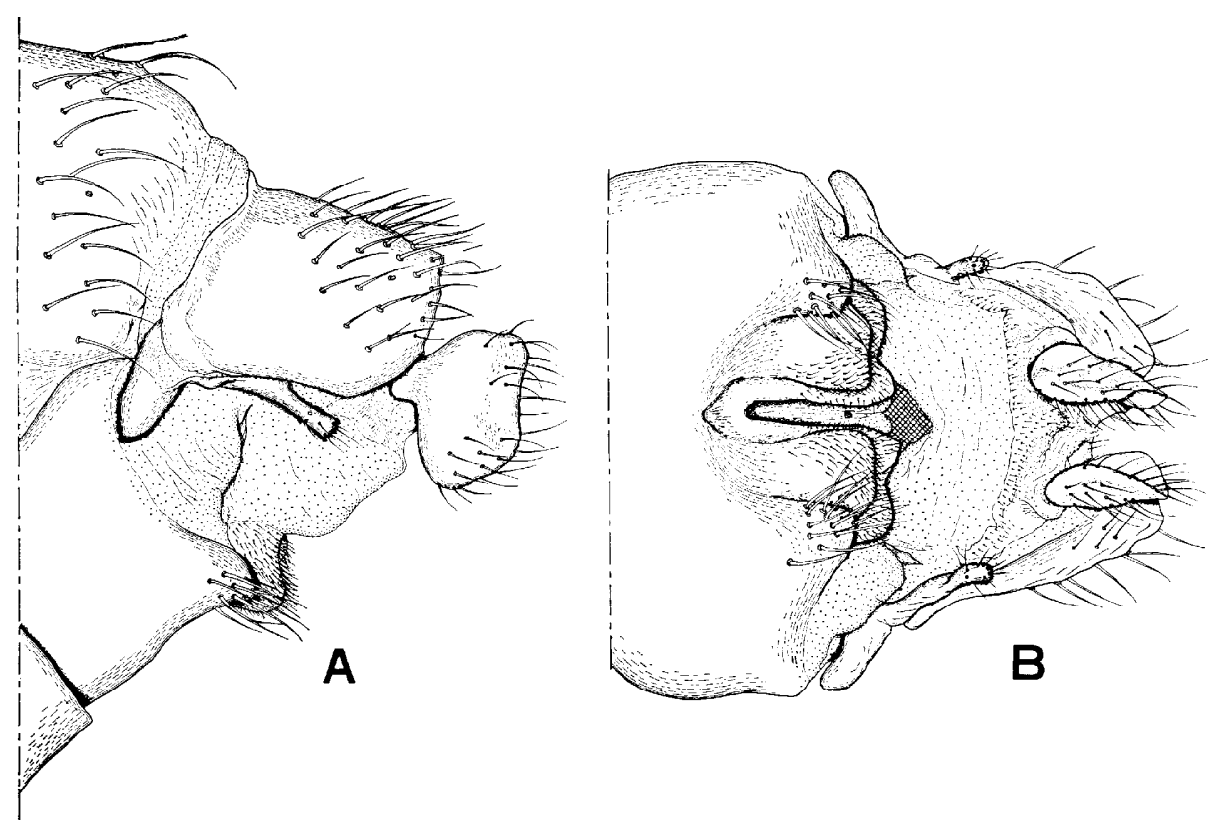

Fig. 7. Female genitalia of Chasmatonotus unilobus sp. nov. A: lateral aspect. B: ventral aspect.

1-3 annular organs on middle anteriorly, 4-7 annular organs on apical part, and with 4-7 setae near middle. Squama with 1-5 setae.

Genitalia (Figs. 7-A, -B) : Laterosternite strongly lobate basally, its apical part with comparatively short projection which bears about 10 setae on apical $1 / 2$. Coxite VIII with 10-17 long setae.

Length of body: 1.9-2.8 $\mathrm{mm}$.

Distribution : Japan (Honshu).

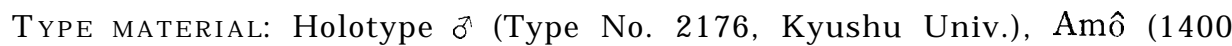
m), Hida-Kawai, Gifu Pref., Honshu, 12. vi. 1977, M. Yamamoto leg. Para-

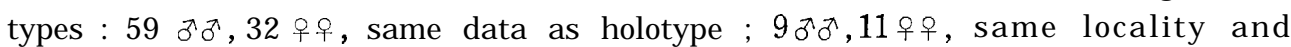
date, K. Ôhara leg.

The holotype is deposited in the collection of the Entomological Laboratory, Faculty of Agriculture, Kyushu University, Fukuoka.

REMARKS: This species can be distinguished at a glance from two other Japanese species in having the widened and parallel-sided gonocoxite, very simple basal lobe and apically bilobed basal projection of the gonostylus in male. The female geniatlia of the new species is very characteristic in having the strong basal lobe on the laterosternite.

The type-specimens were found at the moist herbaceous place near the high moor in woods. 


\section{Chasmatonotus parabicolor sp. nov.}

ð. Colouration: Head, thorax and legs almost as in Chasmatonotus unilobus sp. nov., but antepronotum paler. Wing marking resembling unilobus, but the ground colour of dark area more uniformly brown, apical $1 / 5$ of cell $\mathrm{M}$ and middle of cell A slightly darker. Abdomen brownish black, thinly grey pollinose; basal 4 segments yellow to yellowish brown, darker posteriorly. Genitalia brownish black, thinly grey pollinose.

Head : Antenna1 flagellomere lengths $(\mu): 80,38,33,35,78$. First to 5 th flagellomeres with $11-12,4,4,5,7-9$ setae respectively. Antenna1 ratio 0.42 . Second to 5th palpal segment lengths $(\mu): 73,139,143,184$, and the palpal segments with 9-16, 37-43, 26-36, 16-25 setae respectively. Vertex, clypeus and gena with 16-21, 16-23, O-2 setae.

Thorax : Lateral antepronotals 11-12, median antepronotals 5-7 ; dorsocentrals 21-27, irregularly biserial ; acrostichals S-15, prealars 6-9, no supra-alar ; scutellars 20-21, biserial. Preepisternum with 3-6 setae.

Legs : Fore-, middle and hind coxae with 20-30, 11-17, 21-26 apical setae respectively. Middle coxa with 9 minute sensory hairs on its middle portion of outer surface. Fore-, middle and hind trochanters with 36-48, 30-39, 31-35 apical setae respectively. Outer spur of hind tibia 1.5-1. 6x as long as inner one. Tibia1 comb of hind leg composed of 12-14 spines.

Lengths (means, $0.01 \mathrm{~mm}$ in unit) and proportions (ranges and means) of legs :

\begin{tabular}{lcccccccccc}
\hline & $\mathrm{F}$ & $\mathrm{T}$ & $\mathrm{Tal}$ & $\mathrm{Ta} 2$ & $\mathrm{Ta} 3$ & $\mathrm{Ta} 4$ & $\mathrm{Ta} 5$ & BV & s v & LR \\
$\mathrm{P}_{1}$ & 117 & 116 & 76 & 42 & 29 & 19 & 15 & $2.84-3.02,2.93$ & $3.07-3.20,3.15$ & $0.62-0.65,0.64$ \\
$\mathrm{P}_{2}$ & 108 & 112 & 47 & 27 & 21 & 14 & 13 & $3.34-3.79,3.59$ & $4.53-4.79,4.70$ & $0.41-0.43,0.42$ \\
$\mathrm{P}_{\mathbf{3}}$ & 129 & 136 & 70 & 39 & 29 & 15 & 14 & $3.30-3.63,3.45$ & $3.71-3.90,3.78$ & $0.50-0.53,0.52$ \\
\hline
\end{tabular}

Wing (Fig. 4-B) : Length 1.8-2.0 mm. Width 0.5-O. 6mm. L/WR, range 3.20-3.45, mean 3.35. VR, range 0.94-1. 00, mean 0.98. $R, \mathrm{R}_{1}$ and $\mathrm{R}_{4+5}$ with 26-37, 9-14, 21-28 setae respectively. Radialis with 8-10 annular organs on its basal part, 2 annular organs on middle anteriorly, 3-7 annular organs on apical part, and with 3-7 setae near middle. Squama without setae.

Genitalia (Figs. 8-A, -B, -C, -D) : Anal point (Fig. 5-B) short, with dorsal margin almost straight. Gonocoxite strongly tapering towards apex, inner margin of its ventral surface simple on apical $1 / 2$, not expanding inwardly, therefore inner surface of ventrodistal portion visible from beneath, the surface bearing some long curved setae ; inner margin of ventral surface strongly angulate in middle and with a transverse elevation running dorsally from the angle; dorsal part of basal lobe slightly developed and with some setae, ventral part of basal lobe projected into a short, rather broad process which 

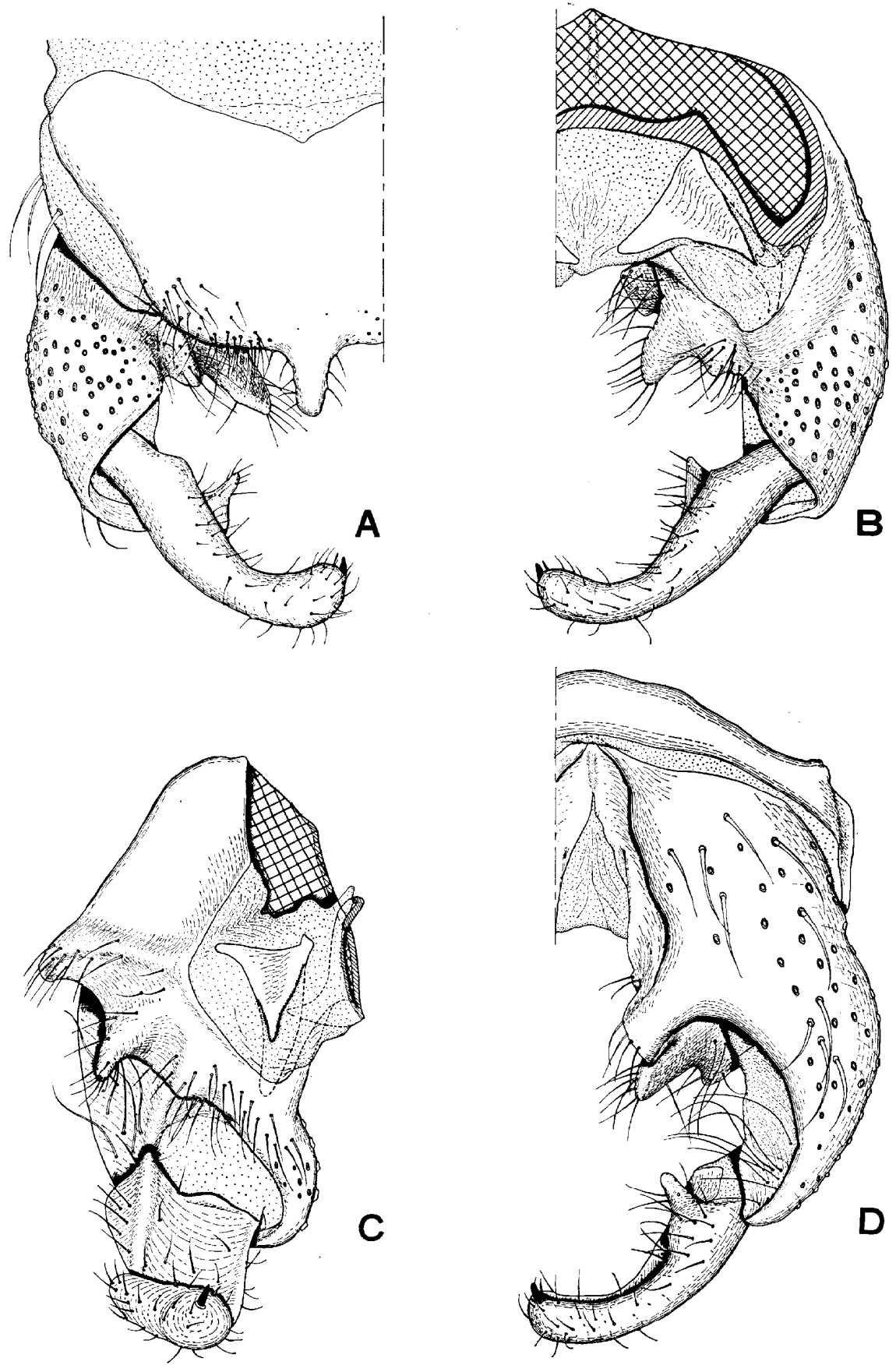

Fig. 8. Male genitalia of Chasmatonotus parabicolor sp. nov. A: epandrium, gonocoxite and gonostylus in dorsal aspect. B: gonocoxite and gonostylus in dorsal aspect. C: same, inner lateral aspect. D: hypandrium, gonocoxite and gonostylus in ventral aspect, 
bears some setae near apex. Gonostylus resembling that of unilobus in general appearance, but basal projection not bilobed, a longitudinal elevation running from tip of the basal projection; extreme tip with a strong spine.

Length of body: $2.0-2.3 \mathrm{~mm}$.

우. Colouration almost as in male. Abdomen pale brown; basal 2 segments yellow, following segments pale brown, darkened towards tip; cercus yellow.

Head: Antenna1 flagellomere lengths $(\mu): 103,45,34,43,85$. First to 5 th flagellomeres with $11,5,6,5,7$ setae respectively. Antenna1 ratio 0.38. Second to 5th palpal segment lengths $(\mu): 40,75,98,120$, and the palpal segments with $16,50,43,18$ setae respectively. Vertex, clypeus and gena with 20, 22, 2 setae respectively.

Thorax : Lateral antepronotals 16, median antepronotals 10 ; dorsocentrals 32 , irregularly biserial ; acrostichals 11, prealars 12, no supra-alar; scutellars 23, biserial. Preepisternum with 14 setae.

Legs: Fore-, middle and hind coxae with 32, 17, 25 apical setae respectively. Middle coxa with 8 minute sensory hairs on its middle portion of outer surface. Fore-, middle and hind trochanters with 48, 39, 33 apical setae respectively. Outer spur of hind tibia $1.7 \times$ as long as inner one. Tibia 1 comb of hind leg composed of 15 spines.

Lengths (means, $0.01 \mathrm{~mm}$ in unit) and proportions (means) of legs:

\begin{tabular}{ccccccccccc}
\hline & $\mathrm{F}$ & $\mathrm{T}$ & $\mathrm{Tal}$ & $\mathrm{Ta} 2$ & $\mathrm{Ta} 3$ & $\mathrm{Ta} 4$ & $\mathrm{Ta} 5$ & $\mathbf{B V}$ & $\mathbf{s ~ v}$ & LR \\
\hline $\mathrm{P}_{\mathbf{1}}$ & $\mathbf{1 2 3}$ & $\mathbf{1 2 5}$ & $\mathbf{7 0}$ & $\mathbf{3 8}$ & $\mathbf{3 0}$ & $\mathbf{2 0}$ & $\mathbf{1 5}$ & $\mathbf{3 . 1 0}$ & $\mathbf{3 . 5 4}$ & $\mathbf{0 . 5 6}$ \\
$\mathrm{P}_{2}$ & $\mathbf{1 1 8}$ & $\mathbf{1 2 3}$ & $\mathbf{4 3}$ & $\mathbf{2 8}$ & $\mathbf{2 3}$ & $\mathbf{1 5}$ & $\mathbf{1 5}$ & $\mathbf{3 . 5 3}$ & $\mathbf{5 . 6 5}$ & $\mathbf{0 . 3 5}$ \\
$\mathrm{P}_{\mathbf{3}}$ & $\mathbf{1 4 3}$ & $\mathbf{1 5 0}$ & $\mathbf{7 5}$ & $\mathbf{4 3}$ & $\mathbf{3 0}$ & $\mathbf{1 8}$ & $\mathbf{1 5}$ & $\mathbf{3 . 5 0}$ & $\mathbf{3 . 9} \mathbf{9 0}$ & $\mathbf{0 . 5 0} \mathbf{5 0}$ \\
\hline
\end{tabular}

Wing: Length $2.4 \mathrm{~mm}$. Width $0.8 \mathrm{~mm}$. L/WR 3.00. VR 1.00. R, $\mathrm{R}_{1}$ and $\mathrm{R}_{4+5}$ with 46,25 , 35 setae respectively. Radialis with 8 annular organs on its basal part, 1 annular organ on middle anteriorly, 8 annular organs on apical part, and with 6 setae near middle. Squama with 1 seta.

Genitalia (Figs. 9-A, -B) : Laterosternite completely separated from 9th tergite, and with an apical projection which is long, slender and bears more than 10 setae on its apical $1 / 2$. Coxite VIII with 19 long setae.

Length of body: $2.3 \mathrm{~mm}$.

Distribution: Japan (Honshu).

Type material: Holotype $ð$ (Type No. 2177, Kyushu Univ.), Mt. Shiroumadake (1600-2600 m), Kita-Azumi-Gun, Nagano Pref., Honshu, 16. viii. 1962, T.

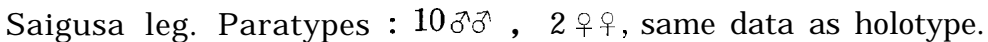

The holotype is deposited in the collection of the Entomological Laboratory, Faculty of Agriculture, Kyushu University, Fukuoka.

REMARKS: In general appearance this new species much resembles Nearctic 

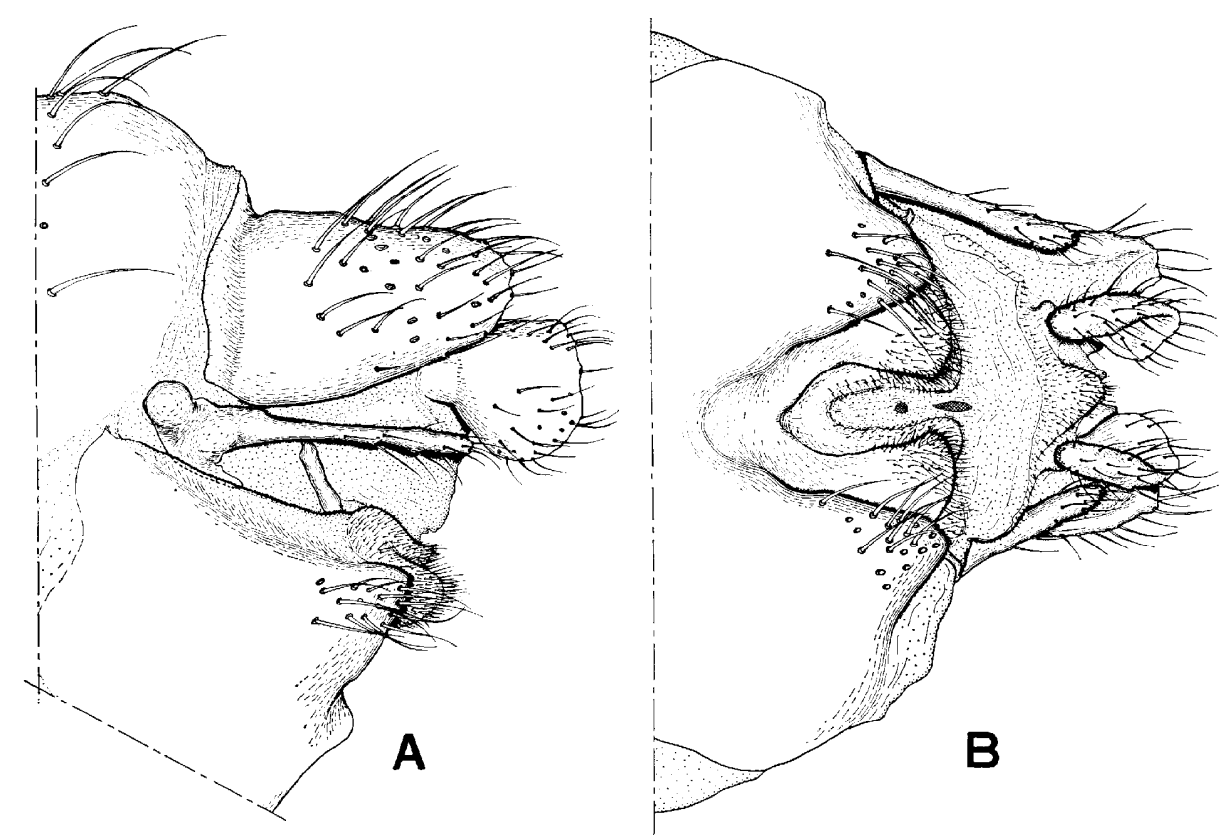

Fig. 9. Female genitalia of Chasmatonotus parabicolor sp. nov. A: lateral aspect. B: ventral aspect.

C. bicolor Rempel, 1937, in which the anal point is stouter, the basal lobe of the gonocoxite well developed and much strongly expanded posteriorly, and the gonocoxite strongly bent subbasally.

The female of the new species may be distinguished from C. saigusai sp. nov. by the longer apical projection of the laterosternite.

\section{Chasmatonotus saigusai sp. nov.}

o. Colouration : Head paler than in C. parabicolor sp. nov. Antepronotum yellow to yellowish brown, proepisternum brown, proepimeron yellow to yellowish brown, postpronotum yellowish brown. Mesonotum subshining deep reddish brown; scutum yellow on anterior $1 / 6$ and around postpronotum, scutellum and postnotum subshining dark brown. Thoracic pleura subshining yellowish brown to dark brown, thinly grey pollinose. Legs almost as in two preceding species but slightly paler. Wing marking resembling that of C. unilobus sp. nov., cell $\mathrm{Cu}$ slightly tinged with yellowish brown. Halter yellow. Abdomen predominantly yellowish brown to dark brown; basal 2-3 segments yellow to pale yellowish brown, darkened posteriorly. Genitalia dark brown, thinly grey pollinose.

Head : Antenna1 flagellomere lengths $(\mu): 115,38,40,43,85$. First to 5 th flagellomeres with $14,6,6,6,8$ setae respectively. Antenna1 ratio 0.36. Sec- 

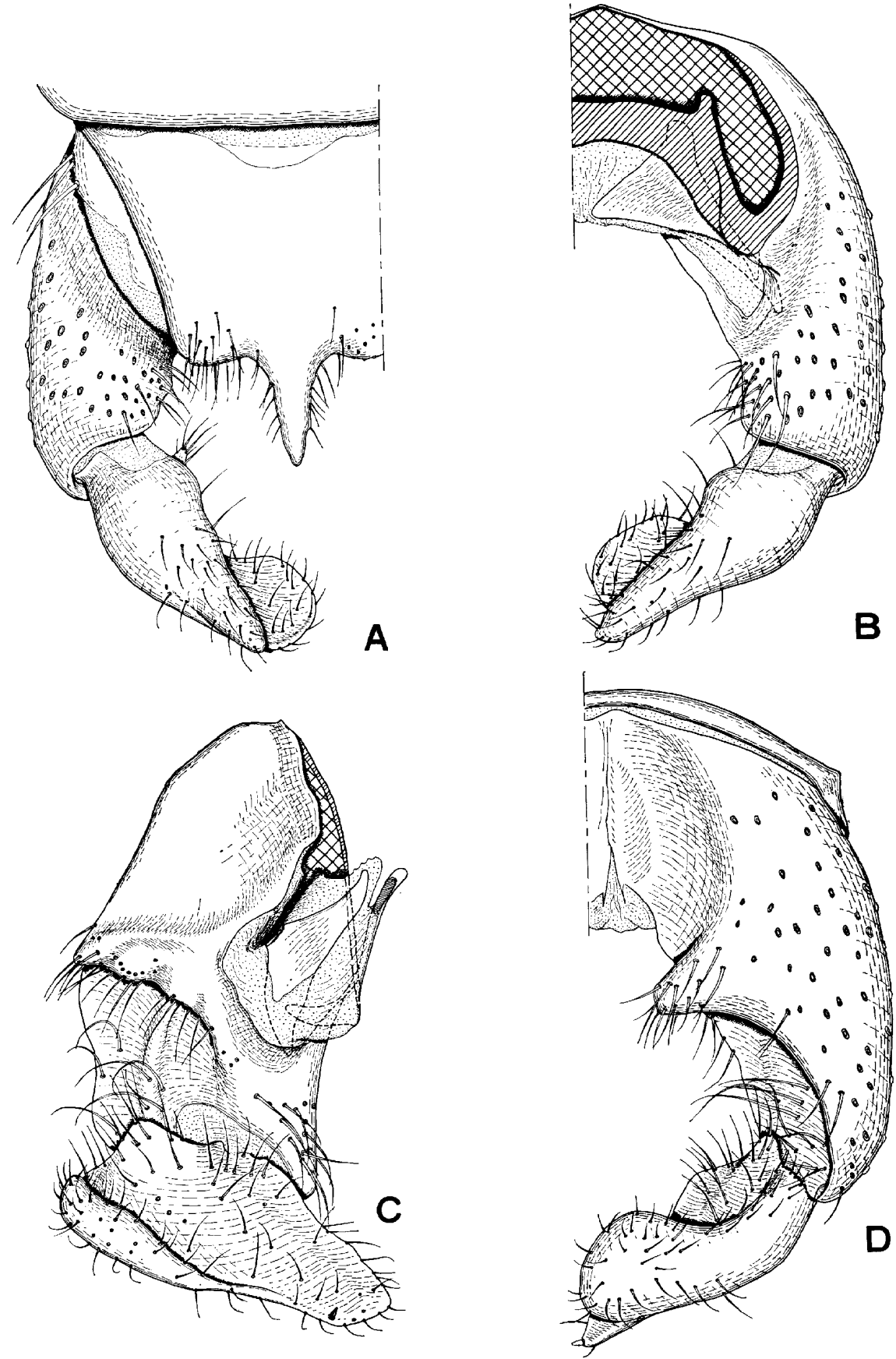

Fig. 10. Male genitalia of Chasmatonotus saigusai sp. nov. A: epandrium, gonocoxite and gonostylus in dorsal aspect. B: gonocoxite and gonostylus in dorsal aspect. C: same, inner lateral aspect. D: hypandrium, gonocoxite and gonostylus in ventral aspect. 
ond to 5th palpal segment lengths $(\mu): 70,133,118,163$, and the palpal segments with $8-9,30-34,20-25,12-15$ setae respectively. Vertex, clypeus and gena with 23-25, 16-21, O-2 setae respectively.

Thorax : Lateral antepronotals 14-15, median antepronotals 9-10;dorsocentrals 17-26, uniserial; acrostichals 13-14, prealars 7-8, no supra-alar; scutellars 21, biserial. Preepisternum with 5-7 setae. Posterior anepisternum with 1-3 setae.

Legs : Fore-, middle and hind coxae with 26-37, 11-21, 23-29 apical setae respectively. Middle coxa with 7-9 minute sensory hairs on middle portion of outer surface. Fore-, middle and hind trochanters with 26-31, 29-31, 19-26 apical setae respectively. Outer spur of hind tibia 1.6 as long as inner one. Tibia1 comb of hind leg composed of 13 spines.

Lengths (means, $0.01 \mathrm{~mm}$ in unit) and proportions (ranges and means) of legs :

\begin{tabular}{ccccccccccc}
\hline & $\mathrm{F}$ & $\mathrm{T}$ & Tal & Ta2 & Ta3 & Ta4 & Ta5 & BV & s v & LR \\
\hline $\mathrm{P}_{1}$ & 118 & 119 & 75 & 46 & 33 & 23 & 15 & $2.67-2.68,2.68$ & $3.06-3.26,3.15$ & $0.62-0.65,0.63$ \\
$\mathrm{P}_{2}$ & 109 & 111 & 48 & 30 & 23 & 16 & 13 & $3.19-3.41,3.29$ & $4.48-4.82,4.63$ & $0.42-0.44,0.43$ \\
$\mathrm{P}_{\mathbf{3}}$ & 128 & 140 & 75 & 41 & 31 & 18 & 14 & $3.24-3.37,3.30$ & $3.56-3.57,3.57$ & $0.53-0.54,0.54$ \\
\hline
\end{tabular}

Wing (Fig. 4-C) : Length 1.9-2. Omm. Width $0.6 \mathrm{~mm}$. L/WR, range $3.24-$ 3.35, mean 3.30. VR, range 1.00-1.04, mean 1.02. $R, R_{1}$ and $R_{4+5}$ with 29-44, 7-16, 24-30 setae respectively. Radialis with 10 annular organs on its basal part, 2 annular organs on middle anteriorly, 7-8 annular organs on apical part, and with 4-5 setae near middle. Squama with O-2 setae.

Genitalia (Figs. 10-A, -B, -C, -D) : Anal point (Fig. 5-C) moderately long, blade-shaped, with weakly emergiante dorsal margin. Gonocoxite resembling that of parabicolor but transverse elevation of middle area weaker, both basal lobes only slightly swollen; inner surface of ventrodistal portion with some long curved setae. Gonostylus (Figs. 5-D) very characteristic, moderately large, subtriangular in shape, inner area strongly concaved and with a weak longitudinal eminence near dorsal edge, with 1-2 stout spines near tip.

Length of body :2.0-2.3 mm.

우. Colouration almost as in male, but in darker specimens thorax as in parabicolor. Colouration of abdomen as in parabicolor.

Head: Antenna1 flagellomere lengths $(\mu): 118,45,26,26,76$. First to 5 th flagellomeres with $12,6,6,6,6$ setae respectively. Antenna1 ratio, range 0.29-o. 35, mean 0.31. Second to 5th palpal segment lengths $(\mu): 80,147,147$, 217 , and the palpal segments with 10-11, 33-39, 24-28, 19-22 setae respectively. Vertex, clypeus and gena with 19-31, 16-18, O-l setae respectively.

Thorax : Lateral antepronotals 13-14, median antepronotals 5-9 :dorsocentrals 17-34, irregularly biserial ; acrostichals 9-12, prealars 11-13, no supra-alar; 

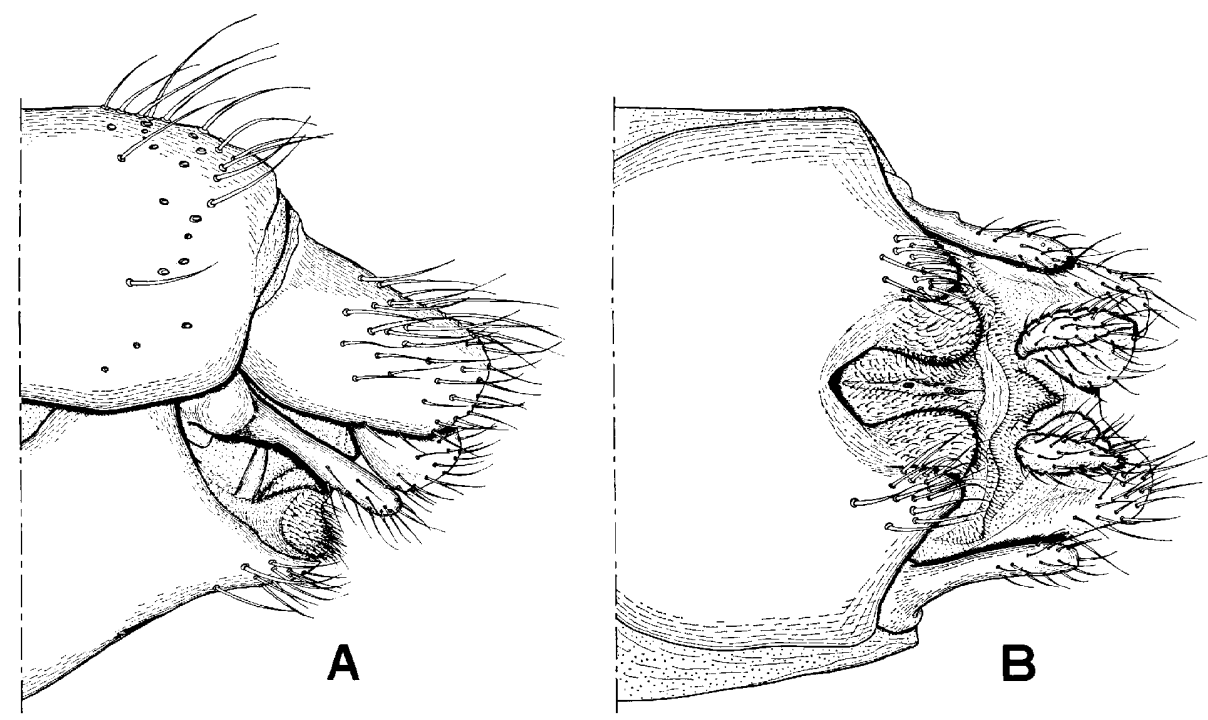

Fig. Il. Female genitalia of Chasmatonotus saigusai sp. nov. A: lateral aspect. B: ventral aspect.

scutellars 22-31, biserial. Preepistenum with 3-7 setae.

Legs : Fore-, middle and hind coxae with 30-36, 13-23, 29-31 apical setae respectively. Middle coxa with 9 minute sensory hairs on middle portion of outer surface. Fore-, middle and hind trochanters with 30-31, 24-26, 20-21 apical setae respectively. Outer spur of hind tibia 1.5 as long as inner one. Tibia1 comb of hind leg composed of 12 spines.

Lengths (means, $0.01 \mathrm{~mm}$ in unit) and proportions (ranges and means) of legs :

\begin{tabular}{ccccccccccc}
\hline & $\mathrm{F}$ & $\mathrm{T}$ & $\mathrm{Tal}$ & $\mathrm{Ta} 2$ & $\mathrm{Ta} 3$ & $\mathrm{Ta} 4$ & $\mathrm{Ta} 5$ & $\mathrm{BV}$ & $\mathrm{s} \mathrm{v}$ & $\mathrm{LR}$ \\
\cline { 2 - 10 } $\mathrm{P}_{\mathbf{1}}$ & 129 & 128 & 79 & 48 & 33 & 24 & 16 & $2.69-2.93,2.79$ & $3.14-3.39,3.25$ & 0.60-o. 64, 0. 62 \\
$\mathrm{P}_{2}$ & 128 & 136 & 64 & 36 & 28 & 16 & 15 & $3.40-3.50,3.45$ & $3.69-4.73,4.14$ & $0.42-$ - $52,0.47$ \\
$\mathrm{P}_{\mathbf{3}}$ & 130 & 130 & 66 & 38 & 29 & 18 & 14 & $3.34-3.35,3.35$ & $3.49-4.78,3.94$ & 0.43-o. 56, O. 51 \\
\hline
\end{tabular}

Wing: Length $2.6 \mathrm{~mm}$. Width $0.9 \mathrm{~mm}$. L/WR 2.92. VR $0.98 . \mathrm{R}, \mathrm{R}_{1}$ and $\mathrm{R}_{4+5}$ with $48,14,33$ setae respectively. Radialis with 11 annular organs on its basal part, 3 annular organs on middle anteriorly, 8 annular organs on apical part, and with 6 setae near middle. Squama with 1 seta.

Genitalia (Figs. 11-A, -B) : Structure much resembling that of parabicolor, but apical projection of laterosternite stouter than in parabicolor, and with about 20 setae on its apical $1 / 2$. Coxite VIII with 14 long setae.

Length of body: $2.3 \mathrm{~mm}$.

Distribution: Japan (Honshu).

Type material: Holotype $\precsim$ (Type No. 2178, Kyushu Univ.), Mt. Kinpusan 
(1800-2596 m), Yamanashi Pref., 1. vii. 1963, T. Saigusa leg. Paratypes :2 ðえ, same data as holotype; $1 \delta^{\nwarrow}, 3$ 우, Mt. Senjô-Dake, Nagano Pref., 4. vii. 1963, T. Saigusa leg. ; 1 ð, Tokugô-Tôge (2135 m), 9. vii. 1963, T. Saigusa leg. ;1 ð, 1 오, Karasawa (2600 m), Nagano Pref., 9. vii. 1963, T. Saigusa leg., 4 우우, same locality and same collector, 10. vii. 1963.

The holotype is deposited in the collection of the Entomological Laboratory, Faculty of Agriculture, Kyushu University, Fukuoka.

Remarks: This species is distinguished from all the known species in having the gonocoxite with slightly swollen basal lobes and the gonostylus subtriangular,

\section{References}

Coquillett, D. W., 1905. New nematocerous Diptera from North America. J.N. Y. ent. Soc. 13: 66.

Loew, H., 1864. Diptera Americae septentrionalis indigena. Bed. ent. Z. 8: 50.

Malloch, J. R., 1915. The Chironomidae, or midges, of Illinois, with particular references to the species occurring in the Illinois River. Bull. Ill. State Lab. nnt. Hist. 10: 499.

Rempel, J. G., 1937. Note on the genus Chasmatonotus with descriptions of three new species (Diptera, Chironomidae). Can. Ent. $69: 250-255$. 